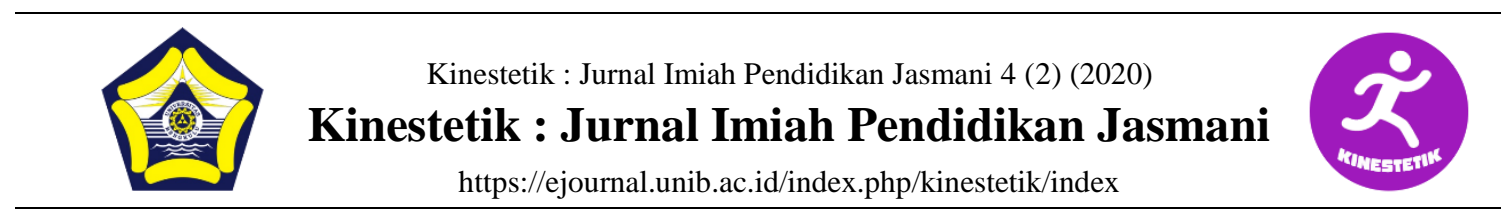

\title{
THE EFFECT OF TEACHING STYLE PRATICE, RECIPROCITY, INCLUSION AND LEARNING MOTIVATION ON BUTTERFLY SWIMMING SKILLS
}

\author{
Rusdi $^{1}$, Firmansyah Dlis ${ }^{2}$, Johansyah Lubis ${ }^{3}$, Anggri Dwi Nata ${ }^{4}$, Whalse ${ }^{5}$ \\ ${ }^{123}$ Pascasarjana, Universitas Negeri Jakarta, Jakarta, Indonesia \\ ${ }^{4}$ Universitas Karimun, Karimun, Indonesia \\ ${ }^{5}$ IKIP PGRI Pontianak, Kalimantan Barat, Indonesia
}

\section{Article Info}

Article History:

Received September 2020

Revised September 2020

Accepted September 2020

Available online September 2020

Keywords: teaching style, motivation, swimming

\begin{abstract}
Teaching styles have a very big role in improving students' learning abilities, by various learning styles it is hoped that students can find most appropriate teaching style that can improve student skills in learning, especially in the basic motion course of swimming. The training teaching style, reciprocity, inclusion of Mosston was selected in this study and learning motivation as the moderator variable was divided into 2 parts, they're high and low. to determine the effect of teaching Style Pratice, reciprocal inclusion and learning motivation on butterfly swimming skills in male students at the Sports and Health Sciences Faculty. Method used in this study is an experimental method with a $3 \times 2$ factorial design. Subjects in the study were male students at the Sports and Health Education Faculty, Teachers' Training Institute, Indonesia Teachers Association, Pontianak. Based on the study results, it's known that the reciprocal teaching style is better than teaching Style Pratice, the inclusion teaching style is better than the teaching Style Pratice and the inclusive teaching style, reciprocity is equally good in learning butterfly style swimming skills in male students at FPOK IKIP PGRI Pontianak.
\end{abstract}

Corresponding address : Jln.H Rais A rahman kalbar

Email : rusdi_por16s3@mahasiswa.unj.ac.id
ISSN 2685-6514 (online)

ISSN 2477-331X (print)

DOI : $10.33369 /$ jk.v4i2.12574 


\section{INTRODUCTION}

Education is the main point in improving human quality life as a whole. Whether we realize it or not, education makes the it more better, in science and technology the role of a lecturer in providing teaching is demanded to be able to adjust to the students needs. The teaching style where the lecturer dominates, especially in sports learning, makes students more accepting and only following what the lecturer says or orders, this makes students not creative, afraid, just following the lecturer's orders, sometimes without knowing the benefits of learning, so that a sense arises. bored, with the teaching style of his lecturer. Inappropriate teaching style can affect students' desire to learn. Boyce (in Johansen), said that learning proccess influenced by teacher's style (Lan Johansen et al, 2015).

Dare to change the teaching styles pattern that are usually monotone and centralized to lecturers must changed to centralized to students, increase creativity and give responsibility in carrying out the tasks assigned by the lecturer, this is where the lecturers role is demanded to be observant and dare to make changes. In the research of Juan Manuel et al (Diuniversity of Seville) which was carried out on 161 samples, the results said a way to develop teaching styles was needed to improve performance abilities and the need for variation in learning (Juan et al, 2016). To cover the shortcomings of a teaching style that is centralized to the lecturer (command), it requires a variety of teaching styles that make students more interested and challenged to develop their creativity. Some teaching styles that give the role of students to be more active than the lecturers are training style, reciprocal style and inclusion style.

These styles advantages are students have the opportunity to further explore their respective abilities both individually in training style, and in pairs by reciprocal style, both those who have more abilities individually and students who have less abilities in the inclusion style so that variations in style The teaching creates learning motivation for students to develop their own potential, be confident and eliminate boredom. Uzer said that teaching style is a way for teachers to carry out the learning process and interact, so that students avoid feeling bored so that students become more diligent and active in learning (Uzer, 1993).

Some advantages of three styles include: training styles provide opportunities for students to develop their creativity in learning, give students the opportunity to develop according to their potential, students who have good experiences will find it easier to learn new material, reciprocal style help create good cooperation between students, develop patience and tolerance, there's reciprocity in learner and feedback recipient, the development of appreciation for the honesty of observer, meanwhile the inclusive teaching style provides opportunities for individuals to advance both who have good abilities and those who have the ability what is lacking, students develop their own concepts with regard to learning the appearance of motion,students can choose to enter from 
the level that suits their ability (Mosston, 1994).

In addition, student learning motivation also has a very important role in improving learning abilities, where when students have high learning motivation they have a sense of desire to advance and compete. Lecturers who are creative in class processing in learning and can find solutions to increase student motivation are what students really need, according to Shahrzad et al. There are many obstacles and ways to increase children's motivation in classroom learning which are divided into 3 parts: using various teaching styles, increasing collaboration and communication, teaching styles used to improve classroom management so that children are motivated (Shahrzad, 2017). The facilities and infrastructure as well as the teaching style of lecturers can foster a desire to learn that motivates these students. according to Elena, the way teachers provide assessments is one key in increasing student motivation in learning (Elina, 2009).

According to Suyoto, learning is a way to gain knowledge, improve skills, improve behavior and ethics in attitude strengthen personality (Suyoto, 2014). Richard, learning is the process of obtaining new, or modifying existing, knowledge, behavior, skills, values or references (Richard Mayer, 2001) Gage changes in behavior as a result of experience, the most important thing is input in the form of stimulus and output. in the form of a response. (Gage, Berliner, 1998), meanwhile Illeris in Sharan said learning as a process that unites cognitive, emotional, environmental influences, to gain experience, changes in knowledge, skills, values and views of the world (Sharan, 2000).

Hirokazu said about walking, jumping, also running are behavior and movement patterns that are developed which can be called skills. With good mobility, you can get what you want so that movement activity is very important for humans. motor learning isvarious kinds of adaptive processes in motor control with new acquired motor skills (skill acquisition) or motor performance under a new kinematic or dynamic environment (Hirokazu, Mitsuo 2009). Croce in Horvat, Saying The theory of motion learning emphasizes that skills are acquired using specific strategies and refined through many repetitions and transfer of skills to other tasks (Horvat et al, 2019). Meanwhile, Krakauer said motion learning is a term that is defined flexibly which includes motor adaptation, skill acquisition, and decision making (Krakauer \& Mazzoni, 2011).

To improve the butterfly style swimming skills. Learning motion is closely related to training in the process of improving movement skills. Learning motion (motor learning) is a change in movement behavior obtained from the training or experience that has been passed which will be relatively constant. (David L. Galahue, 2009). Ernest said the most difficult style to do is the butterfly style, in addition to requiring flexibility, good technical power and also seriousness in training. (Ernest, 2008). 
This is reinforced by firmansyah in ningsih among swimming styles, the most difficult butterfly style due to the complexity of several other reang styles (Sriningsih, 2017).

Colwin said There are several motion indicators in butterfly style swimming, namely: breathing, hand movements, leg movements, body position and movement coordination (Colwin, 2002). Furthermore, according to Geoffrey, butterfly stroke swimming is the movement of the arms and hands that are hit simultaneously, forming waves, whipping the legs together like a dolphin tail movement and the speed is almost as fast as the freestyle movement. (Geoffrey, 2008).

\section{Research Purposes:}

1. To determine effect of style pratice teaching and teaching styles reciprocally on the learning outcomes of butterfly style swimming skills in FPOK IKIP PGRI Pontianak students, 2. To determine the effect of training teaching styles and inclusion teaching styles on learning outcomes of butterfly style swimming skills in FPOK IKIP PGRI Pontianak students, 3. For knowing the effect of reciprocal teaching styles and inclusive teaching styles on learning outcomes of butterfly style swimming skills in students of FPOK IKIP PGRI Pontianak.

\section{METHOD}

This research was conducted at the Ampera Swimming Pool, West Kalimantan for male students of FPOK, physical and health education study program, the Teachers' Training Institute of Indonesian Teachers Association (IKIP-PGRI) Pontianak which has been divided into 3 groups which were given training, reciprocal, and inclusion teaching styles. The research procedure, before the experimental stage was carried out, a preliminary test was carried out. Furthermore, students who had been divided into groups were given a teaching style according to their group for 12 meetings, meetings according to class hours (once a week) Data collection as a final test carried out by a butterfly stroke swimming skill test as far as 25 meters.

\section{RESULT}

Based on the data analysis and testing of research hypotheses, it can be explained as follows:

1. The difference between the exercise teaching style and reciprocal teaching style on butterfly stroke swimming skills learning outcomes.

The descriptive statistical analysis results showed that the group of students who were given a reciprocal teaching style obtained an average score of 25.37 (mean) better than the average score of 21.12 (mean) for students group who used an exercise style.

2. The difference between training teaching style and inclusion teaching style of butterfly swimming skills.

The descriptive statistical analysis results showed that the group of students who were given an inclusive teaching style obtained an average score of 26.12 (mean) better than the average score of 
21.12 (mean) for the group of students who used the training style.

3. The difference between reciprocal teaching style and butterfly swimming skill inclusion teaching style.

Based on the results, it known that reciprocal teaching styles application and inclusion in FPOK IKIP PGRI Pontianak students has the same effect but is based on the results of the study where the difference in reciprocal mean (25.37) is smaller than inclusion (26.12), so the researchers suggest inclusive teaching styles to be used in learning butterfly style swimming skills.

\section{DISCUSSION}

Giving treatment to students as objects in this study allows the occurrence of shortcomings and weaknesses that need to be considered by further researchers. Maximum supervision, even though it has been made, is certainly not free from limitations and shortcomings. For that we will describe and present it as material for future reference and evaluation, while the weaknesses and limitations of research can be explained as follows:

1. The sample in this study only involved male students who program and participate in swimming courses in the sports study program at IKIP PGRI Pontianak, so the generalization of this research is only in age groups that are almost the same or the same. Other student activities in lectures such as attendance even though it has been controlled and on schedule, sometimes there are still students who are absent or late so that it can affect the results of the research.

2. This study involved a very limited sample they are 48 male students who were divided into 3 teaching styles groups which 1 study group consisted of 16 people for each group. With the number of samples for each group is very small, this will certainly be different if the large study group in terms of learning effectiveness certainly affects the resulting decisions. Therefore, although statistical research hypotheses have been tested at the $\alpha$ level of 0.05 , it still needs to be further tested on a larger sample to reduce the statistical effect of a larger sample.

3. Because what is measured in final result of the treatment is swimming skills. The treatment implementation using physical activity that expends a lot of energy for each student is certainly very varied. In this case, the control of energy intake and expenditure is not carried out for each individual. This situation will certainly affect the study results, because what is measured at the end of the treatment is the learning outcomes of swimming skills.

4. Samples Male students who were involved in this research certainly could not generalized to the female sample.

\section{CONCLUSION}

1. Based on the research results, the reciprocal teaching style is better than exercise teaching style, so 
the researchers suggest using reciprocal style rather than training in the basic motion course of swimming, especially at IKIP PGRI Pontianak.

2. Based on the research results, the inclusion teaching style is better than the training style, so the researchers suggest using the inclusion style instead of training in the basic motion courses of swimming, especially at IKIP PGRI Pontianak.

3. Based on the research results, reciprocal teaching styles compared to inclusive teaching styles, there is a significant increase in both teaching styles. So that the reciprocal teaching style and the inclusive teaching style can and can be used simultaneously in the basic motion courses of swimming, especially at IKIP-PGRI Pontianak.

\section{REFERENCE}

Colwin M. Cecil. Breakthrough Swimming. (United States: Human Kinetics, 2002).

Corlett,Geoffrey. Swimming Teaching Theory And Practice,(London :Kaye \& Ward,2008)

David G, Thomas Ms, Swimming Advance, (Jakarta

PT.Rajagrafindo, 2007)

David Heller, Belajar Berenang, Terjemahan, (Jakarta : Pioner Jaya, 2008).

Elena Cocorada, M.R Luca, M Pavalache-Ilie, Perceived Assessment Style And Learning Motivation, (Buletin Of The
Transilvania University Of Brasov Vol.2(51)-2009)

Ernest w.Maglischo, swimming Fastest(canada:human kinetics, 2008).

Hirokazu, Mitsuo, Theories On Motor Learning (Berlin Heidellberg, Ensiklopedia Neuroscience Springer, 2009) http://doi.org/10.1007/978-3-54029678-2.ISBN 978-3-540-29678-2.

Las Johansen B C, MA Viktoria, Romyr Gabon, The use of teaching style in physical education perceived by graduate students, (Internasional Journal of education and research, Vol 3 No 3 march 2015)

Moh Uzer Usman Dan Lilies S. Upaya Optimalisasi Kegiatan Belajar Mengajar, (Bandung :PT Remaja Rosdakarta.Cet.Pertama,1993).

Muska Mosston And Ashwort, S Teaching Physical Education, Fifth Edition (New York :Macmillan College Publishing Company, Inc, 1994).

Nathaniel L.Gage, A Coseption Of Teaching, Springer Science, (Stanford University School Of Education Stanford,Ca Usa,2009).

Richard A.Schmidt, Motor Learning \&Performance (Los Angeles:Human Kinetics Books, 2014)

Shahrzad Ghiasvandian, Varaei, Yadeghari, Pourrahimi, Aghajanloo. Classroom Magement For Instruction Of Unmotivated Students. (Tehran : Journal of Medical Education And Development. 2017)

Sharan B, Rosemary, Caffarela, Lisa, Baumgarner, Learning In Adulthood :A Comprehensive Guide (Jonh Wiley \&Sons,2012)

S Sriningsih, Keterampilan Renang Gaya Кири Кири Melalui Pendekatan Bermain Dalam Pembelajaran 
Aquatik. Jurnal Pendidikan Jasmani Dan Olahraga-Ejournal. Upi .Edu Volume 9 Nomor 2 September, 2017).

Sunandarti, H., Sugiyanto, S., \& Insanistyo, B. (2017). MEKANIKA GAYA APUNG PADA OLAHRAGA RENANG. KINESTETIK, 1(1).

Suyono dkk, Belajar dan pembelajaran, Bandung, Pt.Remaja Rosdakarya, 2014.

Zeng, Howard Z, Differences between student teachers implementation and perceptions of teaching styles, (Journals@sagamorepub.com.v73 n2 2016) 